\title{
PLANO REAL, PRIVATIZAÇÃO DOS BANCOS ESTADUAIS E REELEIÇÃO*
}

\section{Ricardo Borges Gama Neto}

\section{Introdução}

De acordo com a literatura clássica das relações intergovernamentais brasileiras, ${ }^{1}$ o federalismo predatório emergiu nos anos de 1980 como uma das consequências não pretendidas do processo de democratização. A incapacidade de a União ser o mecanismo de coordenação das relações federativas nacionais fez com que os governadores adotassem uma estratégia de conflito com o governo central em torno de questōes tributárias, fiscais, gasto e

* Este artigo é uma versão modificada de parte de minha tese de doutorado defendida em dezembro de 2007, na Universidade Federal de Pernambuco, que contou com o apoio financeiro de uma bolsa de doutorado da Capes. Agradeço os comentários de Marcus André Melo e dos dois pareceristas anônimos da RBCS. endividamento. Contudo, este padrão foi profundamente alterado no primeiro governo Fernando Henrique Cardoso (1994-1998). Reformas econômicas e políticas, conjuntamente com a habilidade do novo governo de utilizar os incentivos e as capacidades institucionais sob seu poder, permitiram ao governo central reformular as relaçôes federativas, estabelecendo padróes rígidos para a renegociação das dívidas estaduais e promovendo a privatização de empresas públicas estaduais, especialmente os bancos estaduais, instituiçôes que permitiam aos governos subnacionais driblar as restriçōes de receitas e adotar políticas de gastos fortemente expansivas e sem cobertura orçamentária.

O paradoxo existente é facilmente percebido: se a União era tão frágil como descreve a literatura clássica do federalismo, como estas mudanças foram possíveis sem alterações profundas no desenho do sistema político brasileiro? Como, sem alterações profundas no desenho institucional, o governo 
FHC recentralizou a capacidade da União de realizar políticas macroeconômicas estáveis? O governo Fernando Henrique impôs ou negociou o refinanciamento da dívida dos estados, em troca do enfraquecimento da capacidade dos governos subnacionais de se endividarem? Para respondermos estas questôes vamos analisar o processo de privatização dos bancos estaduais. Partimos da hipótese de que a redução da atividade bancária dos estados, principal elemento naquele momento da recentralização das relaçôes federativas, foi consequência da negociação pelo governo federal das regras do Proes (Programa de Incentivo à Redução do Setor Público Estadual na Atividade Bancária) e da maior inovação institucional no sistema político brasileiro pós-Constituição de 1988, a reeleição para cargos executivos, fato que mudou profundamente o cálculo estratégico dos governadores de estado em 1998.

Metodologicamente, no trabalho utiliza-se análise documental e testes estatísticos para fundamentar a argumentação apresentada. De uma forma geral, podemos concluir que as mudanças nas relaçôes federativas foi um amplo processo de negociações em que os atores envolvidos, o governo federal e os estados chegaram a uma situação de second best. Os acordos não foram as primeiras preferências de nenhum dos atores, mas satisfizeram a todos dentro do contexto econômico e político da segunda metade da década de 1990.

$\mathrm{Na}$ primeira parte deste artigo apresentamos a argumentação da literatura clássica do federalismo brasileiro; na segunda o processo de implementação do Plano Real, a crise dos bancos estaduais e a negociação entre o governo federal e os governos estaduais das regras para privatização destas instituições financeiras; e por fim, na conclusão, discutiremos os achados do trabalho.

\section{Federalismo, desenho institucional e mudança política}

O federalismo é uma categoria analítica chave para a compreensão do funcionamento do sistema político brasileiro. Melo, ao analisar a agenda de pesquisa da ciência política sobre a temática das políticas públicas e governo, observa que "do ponto de vista da reforma do Estado, o federalismo foi associado às dificuldades de implementá-la e para o $t i$ ming errático de sua implementação no país" (2002, p. 89). O aumento da produção acadêmica sobre o federalismo veio associado a uma mudança de seu status como categoria analítica, passando de um elemento sem muito destaque na literatura para uma "variável independente crucial para o entendimento do conflito distributivo e sua mediação através do regime monetário" (Idem, ibidem).

De acordo com a leitura clássica sobre o sistema político brasileiro, ${ }^{2}$ as relaçôes federativas surgidas durante o período da redemocratização podem ser resumidas da seguinte forma: o processo de descompressão lento e gradual, gerenciado pelos dois últimos governos militares e pelas elites políticas civis, que atuavam no Legislativo federal, iniciou-se com a volta do pluripartidarismo e das eleições diretas para os governos de estado em 1982. O fato de a eleição estadual direta ter ocorrido antes da eleição para presidente, que aconteceu em 1989, tornou os governadores figuras-chaves no processo de transição, e fortaleceu imensamente seus poderes de barganha, tanto dentro dos estados como na política nacional. Isto ocorre, especialmente, por meio do controle que exercem sobre a liberação das verbas utilizadas para o financiamento das políticas públicas nos municípios, as bases locais sob as quais se elegem as bancadas estaduais para as Assembleias Legislativas e o Congresso Nacional. Os Executivos estaduais, durante a redemocratização, retornaram à lógica do processo político do período da República Velha (1989-1930) e da Democracia Populista (1945-1964), passando a ser o núcleo cêntrico das políticas estaduais. O poder dos governadores, no dizer de Abrucio, se "hiperatrofiou", vis-à-vis aos outros poderes estatais, "praticamente eliminando o princípio constitucional da separação e independência entre os poderes" (2002, p. 111).

A forma como o federalismo moldou a política nos estados tornou os governadores capazes de anular os mecanismos formais de checks and balances. Os Executivos estaduais, por serem "os donos do cofre”, conseguem construir maiorias sólidas nas Assembleias Legislativas, mesmo que elejam poucos deputados de seu partido ou da coligação que os apoiou. Os principais mecanismos de conven- 
cimento são os mesmos encontrados à disposição do presidente da República para conseguir apoio parlamentar: cargos, distribuição de verbas do orçamento e convênios.

O presidencialismo brasileiro é considerado de coalizão (Abranches, 1988 e 2001); isto significa que o Executivo federal realiza acordos em que troca apoio político pela seção de cargos na administração a partidos que possuem representação no Congresso Nacional. Idealmente, o presidencialismo de coalizão deveria funcionar numa lógica semelhante ao parlamentarismo, a formação do gabinete seria a troca de cargos por apoio a um projeto político, assumido como responsabilidade de todos. Contudo, de acordo com a literatura clássica, no Brasil a distribuição de ministérios e postos de segundo e terceiro escaláo não acontece sobre o princípio da cooperação partidária, ${ }^{3} \mathrm{em}$ torno de um programa de governo comum. Como a atuação dos partidos políticos na Câmara Baixa não se baseia em amplos programas de políticas públicas, e sim no paroquialismo subnacional, os governadores e os líderes dos partidos procuram agir como embaixadores de seus estados junto ao governo federal. Dessa forma, o Brasil sofreria do que Shugart e Carey (1992) denominam "segredo ineficiente". ${ }^{4}$

Para a literatura clássica, o sistema partidário brasileiro é frágil e acentuadamente desproporcional. Os legisladores constituintes de 1988 não alteraram o modelo de representação proporcional de lista aberta para a Câmara dos Deputados. A disposição espacial dos distritos eleitorais são os próprios estados da federação, e o número de cadeiras colocadas em disputa varia de acordo com a população residente. O tamanho do distrito eleitoral pode ir do mínimo de oito ao máximo de setenta, fortalecendo na Câmara dos Deputados o poder das elites dos estados economicamente menos desenvolvidos. ${ }^{5}$ Os candidatos são eleitos de acordo com o montante de votos que receberem dos eleitores e quando o partido ultrapassa a cota partidária. Estes elementos estimulariam a proliferação de partidos com pequena representação parlamentar, volatilidade eleitoral e comportamento individual dos deputados. ${ }^{6}$

Resumindo, o Brasil sofre de quase todas as patologias institucionais identificadas na literatura sobre custos de governo e déficits fiscais: sistema eleitoral proporcional de lista aberta, partidos políticos institucionalmente frágeis, voto centrado em candidato, amplas e pouco coesas coalizões governamentais. Contudo, apesar de todas as mazelas institucionais identificadas na literatura clássica, o país foi capaz de estabilizar a economia no governo FHC.

Da perspectiva da literatura clássica do federalismo, o sucesso do governo FHC em estabelecer o controle sobre o endividamento público estadual e a estabilização monetária é uma surpresa, algo que simplesmente não deveria ter acontecido! Não houve mudanças profundas na estrutura institucional e nas regras do jogo partidário que justificassem tal sucesso, então o que aconteceu? Como explicar este paradoxo?

O governo Fernando Henrique Cardoso conseguiu construir mecanismos institucionais que aumentaram o controle do Executivo federal sobre o déficit fiscal dos estados, alterando significativamente as relaçōes federativas no Brasil. A renegociação das dívidas em 1997, o processo de privatização dos bancos estaduais e de várias empresas estatais, o aumento da autonomia do Banco Central, a Lei de Responsabilidade Fiscal e a Lei de Crimes Fiscais. Estes fatos suscitam duas perguntas: primeiro, como ocorreu o processo de mudanças nas relações federativas no governo FHC? Houve realmente uma recentralização do poder político na federação??

O governo FHC passou a ajudar os governos estaduais, porque era necessário para a consolidação do Plano Real uma solução duradoura para o problema da dívida dos estados. Parte da literatura defende que as mudanças na economia nacional a partir de 1993, com o estabelecimento do Plano Real e o brusco aumento da taxa de juros, colocaram os governos dos estados em posição de dependência do governo central, que condicionou sua ajuda ao aceite de regras que recentralizaram a federação (Sola e Kugelmas, 2002; Couto e Abrucio, 2003; Regis, 2009). Outra parte afirma que houve um processo de forte negociação, um imenso processo de barganha com a federalização da dívida dos estados, em troca de mecanismos que insulassem o Executivo e a burocracia federal de futuros baiouts (Rodden, 2003).

A seguir, discutiremos a situação econômica e política no Brasil, no momento do estabelecimento 
do Plano Real e depois explicaremos como ocorreu o processo de mudança das relações federativas, tendo como eixo o processo de privatização dos bancos estaduais e a reeleição para cargos executivos.

\section{Governo Itamar Franco e o Plano Real}

A situação da economia brasileira no início de 1993 era dramática! A inflação do ano anterior havia chegado a $1.149,06 \%$ (INPC), o PIB recuado $-0,8 \%$ e a taxa de desemprego aberto era $8 \%$. O governo Itamar Franco, que assumiu após o afastamento de Fernando Collor da presidência da República, demorou alguns meses para iniciar um novo programa de estabilização macroeconômica. Mudanças constantes de ministros, especialmente na área econômica, a falta de uma sólida base parlamentar e um grande escândalo de corrupção envolvendo integrantes da Comissão Mista do Orçamento do Congresso Nacional, que desembocou em uma Comissão Parlamentar de Inquérito (CPI), prejudicavam a articulação governamental. Somente em maio de 1993, com a posse de Fernando Henrique Cardoso, até então titular da pasta das Relaçōes Exteriores, no cargo de ministro da Fazenda, é que o governo adquire mais solidez institucional e política.

\section{Gráfico 1}

\section{Inflação Brasileira de 1980 a 1998 (INPC)}

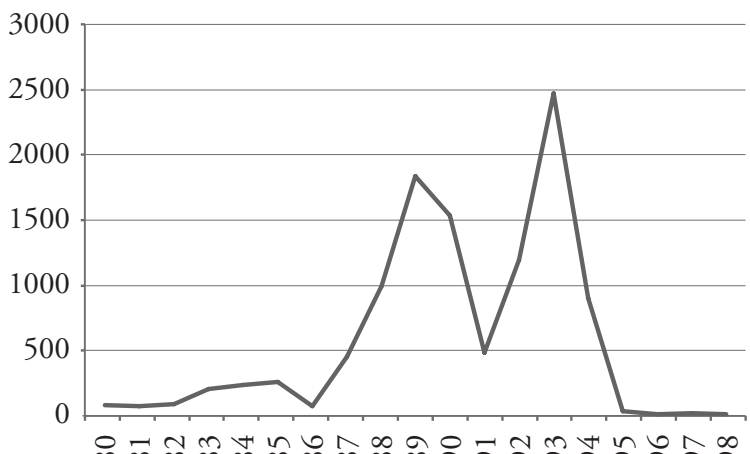

Fonte: Ipedada.

No final de 1993, com a inflação em torno de $2.400,00 \%$, o governo consegue a aprovação de um mecanismo provisório de acerto das contas públi- cas, o Fundo Social de Emergência (FSE). A função do FSE era permitir a redução da rigidez existente entre a vinculação de receitas e o financiamento de despesas não comprimíveis, estabelecidos pela Constituição de 1998. FSE permitiu à União reter $20 \%$ de todas as receitas tributárias do orçamento federal, deduzidas às transferências constitucionais aos estados e municípios, fundos regionais e o Imposto Territorial Rural (ITR).

Em março de 1994, o governo federal institui a Unidade Real de Valor (URV). O objetivo deste instrumento era promover o realinhamento de preços e contratos por um índice comum, fixado diariamente. A URV permitiu a desindexação da economia, retirando o caráter inercial do processo inflacionário. Em 30 de junho de 1994 a URV foi transformada no Real. A nova unidade monetária foi capaz de trazer para o país uma moeda com todas as suas características: unidade de conta; reserva de valor e meio de pagamento. A inflação dos doze meses anteriores foi superior a 5.000,00\%.

\section{Bancos estaduais: crise e privatização}

Os governos estaduais, democraticamente eleitos a partir de 1982, pressionados pelas demandas da sociedade civil e da falta de mecanismos de financiamento decorrentes da crise fiscal do Estado nacional, passaram a ser financiados através da emissão de títulos e debêntures dos tesouros estaduais, empresas estatais, operações de Antecipação de Receita Orçamentária (AROs) e principalmente, dos bancos estaduais que funcionavam como pequenos emissores de "quase-moeda", impedindo que políticas de estabilização macroeconômicas elaboradas e executadas pelo governo federal fossem efetivadas.

Os governadores financiavam-se sem preocupação com a capacidade de solvência dos estados, muitas vezes utilizando mecanismos claramente ilegais, como no caso dos precatórios judiciais em 1997, incentivados pela certeza de que, no final, seriam socorridos pelo governo federal. O federalismo cooperativo brasileiro sofria de um sério problema de moral hazard.

O desajuste fiscal dos governos estaduais ampliava-se a cada programa de estabilização e após 
as eleições. O fim da inflação expunha os desequilíbrios fiscais dos estados, ao retirar das mãos dos governadores o ganho que o floating fornecia aos bancos estaduais e a possibilidade de utilização da inflação como mecanismo de redução salarial. A necessidade de vencer as eleições incentivava a adoção de políticas expansionistas de gastos. Em 1983, 1986, 1991 e 1995, os bancos estaduais apresentaram problemas generalizados de liquidez, forçando o Banco Central a instituir programas de socorro financeiro a tais instituiçōes. ${ }^{8}$ As crises dos bancos estaduais coincidiam com o fim dos ciclos eleitorais.

\section{Gráfico 2 \\ Média do Resultado Primário por Receita Corrente Líquida Anual dos Estados Brasileiros (1986 - 1998).}

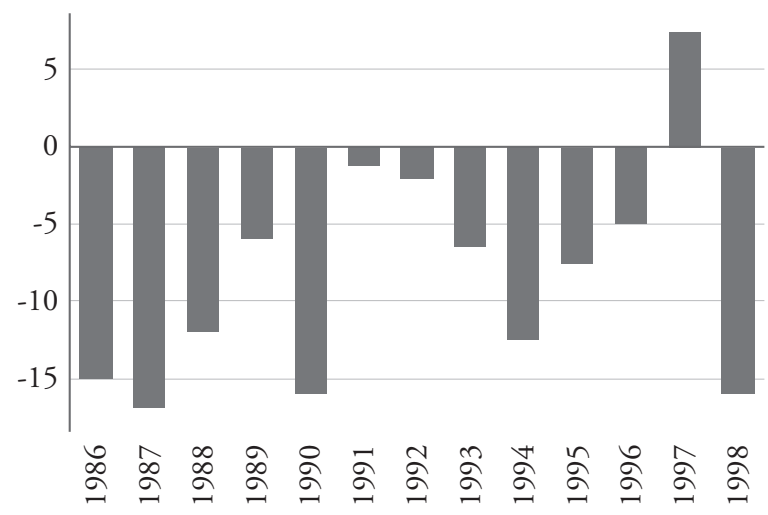

Fonte: Secretaria do Tesouro Nacional.

A solução para as constantes crises financeiras dos bancos estaduais fazia parte da agenda política dos formuladores do Plano Real, e estava coligada diretamente com programas de privatização. A resolução da questão fiscal e de endividamento dos estados era percebida como fundamental para a consolidação de um programa macroeconômico consistente, que produzisse estabilidade de preços e crescimento econômico sustentado em longo prazo. A privatização das empresas estatais estaduais era um dos caminhos necessários para o controle das dívidas dos estados.

O Plano Real, desde seu início, demonstrou ser diferente dos outros programas de estabilização já realizados. Foi feito às claras, apresentado e discutido com a sociedade, realizado em etapas tecnica- mente coerentes e de conhecimento público, apesar da acusação de dirigismo eleitoral que fazia a oposição. Seu sucesso foi imediato, a inflação caiu em julho de $40,00 \%$ para $7,56 \%$ e $1,75 \%$ nos meses posteriores. Depois de uma década de alta inflação, baixo crescimento econômico e programas econômicos que fracassaram, o país possuía um plano que dava certo. $\mathrm{O}$ sucesso imediato dessa (desse) plano elevou a popularidade do ministro da Fazenda, Fernando Henrique Cardoso, que venceu com $54,3 \%$ dos votos sete adversários no primeiro turno da eleição presidencial. A inflação de 1994 foi de 929,32\% (INPC).

O sistema financeiro público estadual era composto por 24 bancos múltiplos, dois bancos comerciais e uma caixa econômica, ${ }^{9}$ e destes, menos de dez possuíam patrimônio líquido insuficiente para cumprir seus compromissos (Folha de S. Paulo, 20/3/1994 apud Kerches, 2001). O Banco Central ciente das dificuldades que atingiam o sistema financeiro estadual, e da situação em que estariam estas instituiçōes depois das eleiçōes, realizou no segundo semestre do ano várias operações de ajuda, dentre as quais destacam-se: troca de títulos das dívidas mobiliárias dos estados por papéis do Banco Central (resolução no 2.081); flexibilização das regras de recolhimento do depósito compulsório destas instituiçôes (circular $n^{\circ} 2.457$ ); autorização para aquelas recolherem o compulsório sobre depósitos judiciais de $100 \%$ do total de recursos, sob forma de papéis de seus controladores (circular no 2.462); operaçōes de redesconto para aumento da liquidez; e por fim, permissão da cessão de créditos dos bancos estaduais para instituições não financeiras pertencentes a seus controladores e a renegociação destes créditos por vinte anos (resolução no 2127). ${ }^{10}$

Fechadas as urnas, o Banco Central passou a negociar com os novos governadores as reformas capazes de dar solvência aos bancos estaduais. Contudo, aproveitando o momento político pós-eleitoral, e diante de imensos passivos a descoberto, o Bacen decidiu intervir nos bancos estaduais de São Paulo e Rio de Janeiro, ambos governados pelo Partido da Social Democracia Brasileira (PSDB), a agremiação partidária do presidente da República. Junto a estas instituições, sofreu intervenção o Banco de Desenvolvimento do Rio Grande do Norte, que estava 
tão deteriorado que entrou imediatamente em processo de liquidação extrajudicial. Depois sofreram intervenção, e colocados sobre regime de administração especial, os bancos dos estados de Alagoas (23/1), Mato Grosso (6/2) e Rondônia (20/2). ${ }^{11}$

De acordo com Gustavo Franco,

Tecnicamente, podíamos ter feito a intervenção nos 30 bancos estaduais no mesmo dia ou pouco antes, mas como estratégia, para lidar com um problema sistêmico, optamos por escalonar, fazendo o mínimo que a lei nos obrigava a fazer naquele momento; ou seja, o banco que está no Redesconto e não tem condições patrimoniais de oferecer garantias precisa de uma intervenção, ou de um regime especial, na mesma hora (Ver <http://www.econ. puc-rio.br/gfranco/CPDOCMario\%20Covas. htm>, acessado em março de 2009).

A situação fiscal dos estados brasileiros era desesperadora no final de 1994 e durante o ano de 1995. A média do resultado primário por receita corrente líquida ${ }^{12}$ foi superior a $10 \%$ negativo, a dívida pública estadual saltou de 44 bilhões de reais em 1993 para mais de 80 bilhôes em apenas um ano, equivalente a $30 \%$ do PIB, com encargos que representavam em média 5\%. Em 1995, as dívidas dos estados ultrapassaram o valor de 100 bilhôes de reais, sendo que $62 \%$ concentradas em quatro estados: São Paulo, Rio de Janeiro, Minas Gerais e Rio Grande do Sul. A despesa de pessoal consumia em média mais de $50 \%$ da receita corrente líquida, sendo pior a situação em estados como Acre (86\%), Pará (70\%), Piaui (71\%). A situação de gasto com funcionários piorou bastante para vários estados no ano seguinte: Amapá de 59\% para 82\%, Brasília de $27 \%$ para $77 \%$, Rio de Janeiro de $67 \%$ para $95 \%$, entre outros. Com o fim da inflação, as instituições financeiras nacionais perderam em média $20 \%$ de seus lucros (Makler, 2000) e os estados ficaram sem seu principal mecanimo de burlo das restriçôes orçamentárias. Não havia solução possível para o problema do endividamento e da crise fiscal dos estados sem a ajuda do governo federal, e devido ao tamanho das dívidas, o Executivo federal decidiu agir de forma imediata.
Paes (1996) observa que em nota emitida à imprensa em 30 de dezembro de 1994, o Banco Central ao explicar as razões de intervenção no Banco do Estado de São Paulo (Banespa) e Banco do Estado do Rio de Janeiro (Banerj), abria a possibilidade de privatização destas instituiçôes. No caso da instituiçãoo carioca, o governo do estado não se opôs e contratou o Banco Bozano-Simonsen para sanear a instituição e posterior privatização. A principal motivação do governo Marcelo Alencar era reduzir a dívida do estado.

O programa de reestruturação do Banerj consistiu na estratégia adotada pelos bancos privados: demissão de funcionários, aumento das taxas de administração e fechamento de praticamente todas as agências existentes fora do estado. Contudo, para conseguir privatizar o Banerj, em 1997, o governo do estado ainda teve de assumir o Previ-Banerj (caixa de previdência dos funcionários do banco), que possuía um passivo de 350 milhôes de reais. ${ }^{13}$

Um fato interessante no processo de privatização do Banerj foi que o governador impetrou Ação Direta de Inconstitucionalidade (Adin 1.348RJ) contra o Art. 69 da Constituição Estadual ("as ações de sociedades de economia mista pertencentes ao Estado não poderão ser alienadas a qualquer título, sem expressa autorização legislativa”) e seu parágrafo único ("sem prejuízo do disposto neste artigo, as açôes com direito a voto das sociedades de economia mista só poderão ser alienadas desde que mantido o controle acionário, representado por $51 \%$ das referidas ações”). Marcelo Alencar pretendia privatizar o banco estadual sem a anuência do Legislativo estadual, , reduzindo bastante, dessa forma, o campo de ação dos opositores à venda do Banerj e a barganha que teria de fazer junto aos deputados estaduais para conseguir a autorização legislativa. O Supremo Tribunal Federal (STF) deu ganho de causa parcial ao governador, tornando inconstitucional o parágrafo único do referido artigo. ${ }^{14}$ Contudo, afirmou que a venda do controle acionário deveria ser feita com base em lei específica aprovada pela Assembleia Legislativa.

No caso do banco paulista, a situação foi bem diferente e a negociação, de acordo com Kerches (2001), estabeleceu muito dos parâmetros legais que foram sendo utilizados pelo governo federal no processo de redução da atividade bancária dos estados. 
Durante todo o ano de 1995, o governo federal negociou com a bancada paulista uma solução para as dívidas do Banespa $;{ }^{15}$ do outro lado, o Bacen e o CMN tentavam auxiliar os demais bancos (Kerches, 2001). O problema é que os estados continuavam com déficits primários, que em parte estavam sendo financiados por meio de operaçóes de ARO, "e os elevados custos desse tipo de operação aumentaram a vulnerabilidade dos governos subnacionais diante das oscilações das taxas de juros" (Mora, 2002, p. 10). Ao mesmo tempo se acirrava a guerra fiscal entre os estados, o que tornava difícil a curto ou a médio prazo uma melhora na arrecadação dos estados. ${ }^{16}$

No final de 1995, o Conselho Monetário instituiu o Programa de Saneamento e Ajuste Fiscal dos Estados, com linha de crédito especial administrada pela Caixa Econômica Federal, para refinanciamento das operações de ARO, e o Banco Central, via resolução 2217, autorizou as instituições financeiras estaduais a concederem crédito a seus controladores com recursos de empréstimos em moeda para liquidação dos débitos oriundos de operações de ARO contratadas com prazo de pagamento de até 24 meses. Os estados comprometeram-se com a adoção de medidas de ajuste fiscal, como a privatização de empresas estatais, contudo não cumpriram o acordo.

$\mathrm{Se}$, de um lado, o governo federal negociava e instituía programas de ajuda às unidades subnacionais e seus bancos, de outro, também endurecia as regras da liquidação extrajudicial. A Medida Provisória $\mathrm{n}^{\circ} 1182$ estabeleceu a responsabilidade solidária dos controladores e a indisponibilidade de seus bens, e ainda forneceu ao Bacen autoridade para realizar operaçōes para recuperação de instituiçōes bancárias, independentemente de estar em regimes especiais.

Em janeiro de 1996, depois de um ano de o Banespa sofrer administração especial, o governo estadual e a União chegaram a um acordo que mantinha o banco sob controle do estado. Metade da dívida do governo de São Paulo com o Banespa, de 14 bilhôes, seria paga com a venda dos ativos de empresas estatais paulistas. O Tesouro Nacional financiaria o restante da dívida. $\mathrm{O}$ protocolo não incluía as dívidas mobiliárias do governo paulista. $\mathrm{O}$ acordo não foi adiante. A oposição do governador do estado, impasses na Assembleia Legislativa do esta- do, no Senado federal e uma CPI para investigar as intervençōes do Banco Central fizeram com que a operação de refinanciamento das dívidas demorasse cinco meses. Quando foi aprovada pelo Senado, a dívida do estado já havia chegado aos 20 bilhōes, e o governador Mário Covas recusou-se a assinar o acordo (Kerches, 2001).

Foram emblemáticas as divergentes posturas dos governadores de São Paulo e Rio de Janeiro diante do problema, sendo todos do mesmo partido do presidente. A defesa da estabilidade monetária e da responsabilidade fiscal era um elemento importante do discurso dos políticos do PSDB, inclusive dos governos estaduais eleitos, contudo uma coisa é a posição de governador, outra, de presidente. Existe em toda a federação um conflito natural e intrínseco entre o governo central e os governos subnacionais, mesmo que sejam de um mesmo partido. A diferença da postura de Mário Covas em relação à postura de Marcelo Alencar na questão da privatização pode ser creditada, em parte, à situação fiscal dos dois estados. ${ }^{17}$ São Paulo estava em posição fiscal muito melhor do que o Rio de Janeiro para negociar com o governo federal; o governo carioca estava em 1995 com um rombo nas contas de $-30 \%$ da sua receita líquida e comprometia $67 \%$ dos seus recursos com pagamento de funcionários. Mesmo que o novo governo paulista tivesse um resultado primário de menos $25 \%$ no início do governo, conseguiu reduzir este déficit para quase zero um ano depois, e comprometia menos de $50 \%$ de seu balanço primário com pagamento de servidores.

A dificílima negociação de um acordo em São Paulo, e as pressōes no Senado para uma solução que também abarcasse os outros estados, fez com que o governo federal dobrasse a aposta sobre a mesa. Em 7 de agosto de 1996, foi editada a Medida Provisória 1514, ${ }^{18}$ instituindo o Programa de Incentivo à Redução da Presença do Estado na Atividade Bancária (Proes).

Grosso modo, a nova legislação pode ser vista como uma extensão a todas as unidades subnacionais de uma versão anabolizada do antigo acordo realizado em São Paulo. A questão central entre o governo paulista e a União era que "as tentativas de trocar dívidas por patrimônio esbarravam num obstáculo intransponível: não havia imóveis que 
nem de longe as compensassem, mesmo nas avaliaçôes mais favoráveis” (Cardoso, 2006, p. 367).

O Proes apresentava duas características importantes, ausente dos outros programas de ajuda financeira aos bancos estaduais, e que tiveram impacto significativo para a dinâmica política interna dos estados: primeiro, era um programa voluntário, a adesão não era obrigatória, ${ }^{19}$ e segundo, ao governo estadual cabia a escolha da forma de participação. Isso trazia para dentro do jogo federativo as escolhas não apenas do governo estadual, mas também do Poder Legislativo local, que deveria dar o aval final por intermédio de uma lei específica. Dessa forma, haveria repartição do ônus da escolha entre a União e as elites políticas estaduais no poder (Kerches, 2001).

O mecanismo central para induzir os governadores de estado e a Assembleia Legislativa a decidirem-se pelas principais preferências do Executivo federal, extinção ou privatização da instituição, era o financiamento de $100 \%$ das dívidas dos estados. Em termos estritamente técnicos, tratava-se de um acordo excelente, livrando o estado de ter que administrar uma instituição quase sempre deficitária num ambiente de alta volatilidade da taxa de juros, e ainda livrando o Tesouro estadual de ter que receber de volta os títulos que havia utilizado como garantia dos empréstimos. Mas havia uma questão: e as outras dívidas, contratual e mobiliárias, como seriam solucionadas?

O desequilíbrio financeiro dos estados era generalizado. As dívidas mobiliárias de curto prazo, especialmente as contraídas por antecipação de receita, altamente influenciadas pela taxa de juros, tornava a relação dívida/receita líquida disponível cada vez mais distante. Em 1996, apenas seis das 27 unidades subnacionais tinham Indicador de Meta Fiscal (IMF), que mensura a relação entre a dívida estadual e a receita líquida corrente, igual ou menor que um, à média nacional de 1,89. Seis estados - Piauí, Minas Gerais, São Paulo, Rio Grande do Sul, Mato Grosso, Mato Grosso do Sul e Goiás - possuíam IMF acima de 2,0 (Mora, 2002). O desajuste era de tal magnitude que, políticas de contração de despesas sozinhas, como os programas de reforma administrativa e reforma administrativa dos estados, não conseguiriam revertê-las. Seu crescimento já era inercial e exponencial.
A negociação de uma solução para o problema da dívida que envolvesse todos os estados e não apenas São Paulo iniciou-se em dezembro de 1996 com a publicação da Medida Provisória 1560. A primeira cláusula estabelecia a data na qual o governo federal esperava poder conseguir efetuar toda a negociação, 30 de junho de 1997. Contudo, o processo foi mais longo, e a MP até se transformar em lei passou de onze para quinze artigos, sem contar as várias letras e incisos inseridos. $\mathrm{O}$ acordo final para a dívida dos estados foi conseguido no início de setembro e materializado na Lei 9496/97, ${ }^{20}$ que instituiu o Programa de Apoio à Reestruturação Fiscal e Financeira. Foi a única, entre as sete rodadas de negociação realizadas entre a União e os estados a partir de 1988, três delas desde 1991, em que o governo central condicionou os empréstimos para o financiamento de dívidas a um amplo ajuste fiscal, patrimonial e cumprimento de metas pelos governos de estado.

Os pagamentos das dívidas assumidas pela União seriam em 360 prestações, com carência de mais dez anos, com juros entre $6 \%$ a $7,5 \%$ ao ano. Vinte por cento do montante renegociado deveria ser entregue sob a forma de bens e direitos para amortização das dívidas à vista. Para manter a capacidade de pagamento dos estados foi estabelecido um limite de comprometimento da receita, que seria entre 11,5 a $15 \%$. Isto variava basicamente por causa da capacidade do estado de pagar os $20 \%$ à vista. Àqueles que não possuíam ativos para o pagamento foram punidos com regras mais restritivas.

As regras para o pagamento do refinanciamento, além de estabelecerem prazos extensos, embutiam forte subsídio implícito. De acordo com Mora (2002), tomando-se como referência uma tabela Price com taxas de juros entre $8 \%$ e $10 \%$ ao ano, e comparando-a com a de $6 \%$ estabelecida nos contratos, chega-se a um subsídio que varia entre $27 \%$ a $88 \%$ do PIB nacional. ${ }^{21}$

No caso de inadimplência do estado, o governo federal tinha o direito de substituir as condiçôes de pagamento do refinanciamento pelo custo médio de captação da dívida mobiliária federal, acrescido de um por cento ao ano, e elevação em quatro pontos percentuais do comprometimento da receita, que valeria enquanto durasse o descumprimento do acordo, sem prejuízo das demais cominaçôes 
pactuadas nos contratos. Nos estados com maior poder econômico, também seriam retidas parcelas do Fundo de Participação dos Estados.

$\mathrm{O}$ acordo de refinanciamento foi excelente para os governos estaduais, revertendo o quadro de insolvência que se abatia sobre os estados. Em 1997 houve um alívio de caixa que permitiu um superávit no Resultado Primário por Receita Corrente Líquida de $7,52 \%$ (que se tornou negativo em $15,78 \%$ no ano de 1998 em face das eleiçōes estaduais). ${ }^{22}$

Analisando os impactos positivos que a renegociação das dívidas estaduais tinha sobre os cofres do Tesouro Estadual do Rio Grande do Sul, o deputado estadual César Buzato (PMDB), em discurso na Assembleia Legislativa do estado, no dia 7 de abril de 1998, afirmou:

O Rio Grande do Sul tomou a dianteira na busca de uma solução estrutural ao problema da sua dívida mobiliária, acumulada ao longo de mais de duas décadas, que alcançou a cifra de 8 bilhões e 100 milhões de reais em 31 de dezembro de 1997. Seu crescimento, a juros de mercado, era de 2 bilhóes e 200 milhôes de reais/ano, 186 milhōes de reais/mês, 6 milhões de reais/dia.

Em 20 de setembro de 1996, [...] o Rio Grande do Sul foi o primeiro Estado brasileiro a assumir e a assinar o protocolo de renegociação global da dívida mobiliária do Estado. Conseguimos condições absolutamente excepcionais. Trinta anos de prazo, taxas de juros fixa de $6 \%$ ao ano, correção monetária pelo IGPDI, da Fundação Getúlio Vargas, 18\% de ativos do Estado para amortizar o estoque da dívida e a data de corte da dívida, a partir da qual ela cresceria apenas $6 \%$ fixos ao ano, estabelecida em 31 de março de 1996.

Se examinarmos a evolução da dívida do Estado, com e sem renegociação, podemos dizer o seguinte: a dívida, hoje, é de 10 bilhōes e 900 milhōes de reais. Cada gaúcho deve 1 mil, 147 reais e 40 centavos. Sem renegociação, no ano 2012 nossa dívida atingiria, aos preços de mercado de hoje, a estrondosa cifra de 76 bilhōes e 900 milhões de reais. Cada gaúcho passaria a dever 8 mil, 94 reais e 70 centavos.

Com a renegociação conquistada, no mesmo ano 2012 essa dívida será de tão-somente 7 bilhões e 200 milhões de reais. Cada gaúcho deverá apenas 756 reais e 50 centavos.

Outras vantagens absolutamente importantes foram alcançadas com a renegociação. O subsídio conquistado pelo Estado desde a data do corte da dívida - 31 de março de 1996 até hoje - é da ordem de 1 bilhão e 200 milhões de reais. A redução da taxa de juros, que é hoje de $28 \%$ ao ano, foi fixada em $6 \%$ ao ano, com uma economia de 1 bilhão e 500 milhões de reais/ano.

Recuperou-se a credibilidade do Estado, que voltou a ter acesso a financiamentos internacionais de longo prazo.

$[\ldots]$

Recuperamos, enfim, as margens operacionais do Banrisul, para que esse banco possa realizar novos financiamentos à atividade econômica gaúcha.

Com a renegociação da dívida do Estado, eliminou-se o crescimento explosivo provocado pelo impacto dos juros sobre a dívida. Ao mesmo tempo, eliminou-se um fardo insustentável que infernizou o Governo Simon, o Governo Guazzelli, o Governo Collares e que tirou o sono do Governador Antônio Britto por três anos e três meses (Disponível em <http://www.al.rs.gov. br/anais/49/plenario/1998/980407.htm>).

Se os estados estavam tão fragilizados, por que o governo federal não conseguiu impor suas primeiras escolhas aos governadores? Nas relações federativas são inerentes os conflitos de interesses entre as unidades subnacionais e o governo central, e em um regime democrático tais disputas pautam-se em acordos firmados pelo Legislativo. Nos regimes democráticos, conflitos não são jogos de soma zero! O comportamento dos atores políticos varia 
de acordo com as regras formais e informais existentes, punições críveis e a ação dos outros atores, ou seja, pautam-se por uma conduta estratégica. Houve uma grande mudança no comportamento do Executivo federal, eleito em 1994, em relação aos governos anteriores: a convicção de que a estabilidade monetária somente seria conseguida com o controle do déficit público dos estados. Era do conhecimento de todos que isto somente poderia acontecer se houvesse a privatização das empresas públicas e a obediência hermética às regras de refinanciamento acordadas. Os governadores tinham consciência disso, tentaram reagir ${ }^{23}$ não conseguiram, mas tinham a seu favor a possibilidade de falência completa dos estados. ${ }^{24} \mathrm{~A}$ falência completa dos estados poderia levar a uma séria crise de governabilidade; exemplos locais abundavam e os casos mais emblemáticos eram Espírito Santo e Alagoas (cujo governador renunciou em julho de 1997). ${ }^{25}$ Ao governo federal interessava dar uma solução para a crise fiscal dos estados, e não levar à federação a bancarrota!

A renegociação das dívidas estaduais e o Proes ocorreram simultaneamente. ${ }^{26}$ De uma perspectiva puramente racional, o timing do processo não ocorreu de forma a privilegiar as escolhas do governo federal. Para a equipe econômica - hard core da administração Cardoso, uma burocracia altamente insulada das influências políticas dos governos estaduais e do parlamento -, o ideal seria realizar primeiro a negociação do Proes e depois das dívidas mobiliárias estaduais. Para o governo federal fechar "a torneira" dos bancos estaduais era mais urgente, por duas razôes: reduzia um sério elemento de desequilíbrio no sistema financeiro nacional e diminuiria o espaço de negociação dos estados, que ficavam sem um instrumento importante de financiamento dos Tesouros estaduais. Mesmo sem poder financiar diretamente seus controladores, especialmente mediante antecipações de receita orçamentária, os bancos estaduais realizavam operações trianguladas de financiamento dos governos estaduais, tanto por meio de créditos a empresas estatais como via empréstimos de baixa qualidade para fornecedores governamentais. Para os governadores, idealmente o timing do jogo era o oposto, livrar-se primeiro das dívidas mobiliárias e depois negociar a questão dos bancos estaduais.
A lógica do programa de redução da atividade das instituiçôes financeiras públicas estaduais era fornecer aos governos dos estados quatro diferentes escolhas condicionadas a duas formas específicas de financiamento das dívidas estaduais e a adoção de medidas de modernização da administração bancária: 1) extinção da instituição; 2) transferência do controle da instituição financeira ao governo federal para privatização; 3) privatização sobre o controle do governo estadual; 4) saneamento.

Da perspectiva dos governos estaduais, que buscaram as linhas do financiamento do programa para o financiamento de suas dívidas, essas quatro escolhas, grosso modo, podem ser transformadas em duas categorias analíticas: as três primeiras (números 1, 2 e 3) significavam a perda do banco. A última, a manutenção da instituição. As preferências dos governos estaduais, sem levarmos em conta os tipos de refinanciamento, podem ser apresentadas da seguinte forma: $([1,2$ e 3$]<4)$.

O ranking de preferências do governo central é bem mais simples; a privatização, a federalização ou a extinção das instituições financeiras estaduais que significam o fim do sistema financeiro subnacional.

A primeira escolha, extinção, aplica-se em três situações: no caso de instituição em processo de liquidação extrajudicial (na qual o estado pouco podia fazer, a não ser pagar as contas e capitalizar seu banco), por meio de processos de incorporação, fusão, cisão ou qualquer outra forma de reorganização societária autorizada pelo Banco Central, ou ainda, pela transformação do banco estadual em Agência de Fomento.

$\mathrm{Na}$ contrapartida federal, se o estado aceitasse entrar no Proes, o financiamento era de $100 \%$ do total das dívidas do Banco, no caso de o governo estadual aceitar a extinção, a privatização ou a federalização da instituição, e de $50 \%$, se a escolha fosse pelo saneamento da instituição. Esta era uma diferença muito importante, não só pelo tamanho da contrapartida do governo estadual, mas também por obrigar esta a ser feita de forma antecipada. ${ }^{27}$ Além disso, as regras do Proes obrigavam a instituição financeira a assumir suas dívidas com terceiros, existentes em 31/1/1996 e registradas em balanço, incluindo passivos de natureza atuarial ou trabalhista e capitalizar o banco. A contrapartida do 
governo federal ainda dependia de manifestação favorável do Banco Central, da Secretaria do Tesouro Nacional e do Conselho Monetário Nacional.

A instituição de Agências de Fomento foi a forma encontrada pela equipe econômica de tornar mais atrativo aos governadores a escolha da principal preferência do governo federal: o fim de uma instituição financeira sob o controle dos estados. Como a argumentação política central para a existência de bancos estaduais era de que os estados deveriam possuir uma instituição financeira que pudesse captar recursos, e depois transferi-los para projetos de desenvolvimento, as Agências de Fomento deveriam servir de estímulo aos governadores na escolha das opçóes. Com a ideia das Agências acreditava-se reduzir a oposição dos estados menos desenvolvidos.

As regras que regem o funcionamento das Agências de Fomento afirmam que cada estado somente pode possuir uma Agência, e estas não são instituiçôes financeiras, apesar de serem subordinadas à supervisão e à fiscalização do Banco Central. Destinam-se a financiar projetos de desenvolvimento no estado, cujos recursos podem ser captados no país ou no exterior, originados de fundos constitucionais, do orçamento de estados e municípios e instituições internacionais. As Agências ainda devem constituir um fundo de liquidez no mínimo equivalente aos seus ativos colocados em risco, a ser totalmente composto de títulos federais.

Discurso e prática são coisas diferentes, e em política esta distinção é crucial. A equipe econômica afirmava que publicamente as regras e os prazos do programa eram inegociáveis, isto porque eram fundamentais para a consolidação do Plano Real, mas na prática o governo federal e os governadores negociavam febrilmente, aproveitando-se das inúmeras reedições da Medida Provisória 1514. A possibilidade de alterar o conteúdo das MPs, a cada reedição, fornecia ao governo federal um grande espaço de manobra para agir, corrigindo erros, introduzindo novas questōes não imaginadas no início de sua confecção e, principalmente, adaptando as medidas à barganha e às conveniências políticas. A variável tempo sempre foi importante no caso do Proes por duas razôes: primeiro, quanto mais demorava a negociação, maior o custo das dívidas e, consequentemente, perda do valor patrimonial da instituição; segundo, todos os atores buscavam uma solução de consenso antes das eleiçôes de $1998,{ }^{28}$ pois o governo federal sabia que quando começasse o processo eleitoral, toda a negociação seria paralisada, e mais, os perdedores das eleiçôes dificilmente teriam condições políticas de negociar uma solução que implicasse a redução da participação do estado no sistema financeiro.

Várias foram as mudanças introduzidas na Medida Provisória 1514 para adequar as preferências do Executivo às dificuldades das negociaçôes políticas. Um dos primeiros problemas que surgiu no debate foi sobre os ativos particulares nas contas dos bancos estaduais. No Proer, a proteção dos aplicadores e correntistas era dada pelo Fundo Garantidor de Crédito (FGC), até o valor máximo de 20 mil reais. Para as instituiçōes financeiras estaduais, a solução foi diferente, e bem mais palatável aos governadores de estado. $\mathrm{O}$ artigo n. ${ }^{\circ} 20$ da quarta reedição da Medida Provisória do Proes (1514-4) autorizou as instituições financeiras federais a assumirem os passivos dos bancos estaduais com o público (cadernetas de poupança, depósitos à vista, investimentos) e afirma que "a União assegurará à instituição financeira federal que assumir os passivos junto ao público a equalização da diferença existente entre o valor a ser recebido da instituição financeira estadual e de seu controlador em decorrência da operação e o valor a ser pago ao Banco Central do Brasil pelos recursos obtidos em linha de financiamento específica para dar suporte aos passivos assumidos" (art. no 20, inciso $1^{\circ}$ da MP 1514-4). Independentemente do valor aplicado, os correntistas dos bancos estaduais receberiam seu dinheiro de volta. Num ano pré-eleitoral, qualquer medida que parecesse ao público bloqueio de haveres monetários poderia ser fatal a qualquer reeleição.

As dificuldades de negociação, especialmente na confecção dos protocolos de intenção que eram estruturados de forma ad hoc, ${ }^{29}$ exigiram que os prazos fixados nas diferentes medidas provisórias fossem constantemente prorrogados. Enquanto alguns estados negociavam rapidamente com o governo federal, especialmente aqueles estados onde a situação fiscal era mais complexa e os governadores apoiavam o presidente da República, como Rio 
de Janeiro, Minas Gerais e Rio Grande do Sul, a maioria protelava a decisão de escolha procurando chegar ao melhor termo nas negociações.

A estratégia de postergar as negociações deu certo para alguns estados, especialmente em relação a um dos grandes problemas do processo de privatização/extinção dos bancos estaduais, o passivo previdenciário. Minas Gerais, em março de 1997, após negociações com o governo federal recebeu um empréstimo-ponte do CMN de 350 milhões para este fim. Santa Catarina, que originalmente se definiu pelo saneamento do Besc, terminou "postergando"30 as negociaçōes até meados de 1999, e conseguiu que a União federalizasse todo o passivo de mais de 500 milhôes do Instituto de Previdência dos Servidores do Estado. O mais interessante da negociação de Santa Catarina é que a federalização do passivo do Instituto de Previdência do Estado de Santa Catarina (Ipesc) também foi uma compensação pelo veto do Senado a uma operação ilegal de emissão de precatórios. ${ }^{31}$

Depois que o governo federal assumiu o passivo previdenciário do banco estadual de Santa Catarina, o governador fez passar na Assembleia Legislativa o projeto de lei que regulamentava a federalização do Banco do Estado de Santa Catarina (Besc), tendo o contrato sido assinado em 30/9/1999.

Goiás também retardou as negociações. $\mathrm{O}$ governador do estado, extremamente bem colocado nas eleiçóes para o Senado, deixou para assinar o contrato depois das eleiçôes de 1998, quando conseguiu fazer seu sucessor. Por sua espera foi premiado:

[...] pelo período de 60 meses após o estabelecimento das regras de pagamento, o novo controlador deverá manter todos os benefícios oferecidos pela CasBEG, instituição responsável por garantir a assistência médica dos empregados do Bando do Estado de Goias (BEG). No caso do BEG ficar desobrigado dos potenciais encargos existentes no PREBEG, fundo de pensão de seus empregados, o comprador terá que ressarcir o governo federal (Bacen, "Relatório Focus", 13/12/2001, p. 2). ${ }^{32}$

Os prazos para assinatura dos contratos de refinanciamento das dívidas dos governos com seus bancos estaduais, fixados nas MP do Proes, foram estendidos quatro vezes. Como observamos, o governo tinha como principal preferência privatizar o maior número de instituições financeiras públicas estaduais, mas a variável tempo que depreciava o valor dos ativos dos bancos incentivava o governo a oferecer mais ajuda para conseguir seu objetivo. $\mathrm{O}$ primeiro dead line foi fixado em 30 de junho de 1997. A MP 1612-18 fixou novo prazo para 31 de dezembro. Novamente fixou nova data, apenas para a opção de saneamento até 31 de março de 1998, e para todas as demais opções 30 de junho de 2000 (MP 1612-19).

Para aumentar suas margens de manobra nas negociações, o governo federal estendeu o prazo final para a vigência do Regime de Administração Especial Temporária (Raet), podendo chegar ao máximo de 450 dias se o governo do estado tivesse assinado o protocolo para implementação das medidas previstas, inclusive privatização. Sem esta prorrogação de prazos, os bancos públicos estaduais que não possuíssem patrimônio líquido suficiente para cumprir suas obrigaçoes bancárias teriam que ser sumariamente liquidados.

Durante os dois primeiros anos do processo de negociação do Proes, a maioria dos governadores se mostrava disposta a manter suas instituiçōes, contudo as benesses de aceitar as preferências do Executivo federal, a incapacidade de levantar os recursos para as contrapartidas, no caso do saneamento (por falta de poder político para mobilizar tais recursos ou a avaliação de que os custos eram altos demais), levaram os governos estaduais a aceitar abrir mão de seus bancos. As eleiçōes aproximavam-se e o adiantamento dos créditos a serem conseguidos com a privatização era um forte estímulo para a assinatura dos contratos. Um exemplo é o caso de Pernambuco. O governador Miguel Arraes demonstrava, inicialmente, a intenção de preservar o banco estadual, ${ }^{33}$ contudo sem condiçōes de bancar a contrapartida exigida pelo governo federal, terminou por aceitar a preferência do Executivo federal. Em junho, o estado assinou com o governo federal o contrato de privatização do Banco do Estado de Pernambuco (Bandepe) e a criação de uma Agência de Fomento. Um mês depois, o Senado autorizou a liberação dos recursos no valor de um bilhão e meio de reais. 
A preocupação com a questão eleitoral fica clara no timing da ação. No início do segundo semestre de 1997, apenas cinco estados "tinham intenção de aderir ao Proes: Rio de Janeiro, Minas Gerais, Mato Grosso, São Paulo, Pernambuco, Alagoas e Rondônia” (Leal, 2000, p. 75). As assinaturas dos contratos do Proes ocorreram, em sua maior parte, no final do primeiro semestre do ano de 1998 - final do prazo para o aceite do caso de saneamento. A maioria dos governos, na falta de condições de manter o banco, optou por privatizar, extinguir ou transformar a instituição em Agência de Fomento. Não houve nenhuma assinatura de contrato durante o período eleitoral. Era importante, tanto para a União como para os estados, resolver a questão antes do início da campanha. Para a maioria dos governadores com sólida base política, a questão era quanto ainda poderiam conseguir, negociando com o governo federal. Ceará, Amazonas e Goiás apostaram em negociar mais e foram premiados com melhores acordos. Para os governadores sem maior poder eleitoral, o ideal era aceitar rapidamente os acordo nos termos feitos pela União, receber os recursos da privatização e investir pesadamente para conseguir melhorar sua posição.

Analisando o risco eleitoral do governador em relação a seus concorrentes, no início do processo eleitoral, pode-se perceber que em vários casos parece existir uma relação entre a assinatura do contrato e a expectativa de vitória ou derrota nas eleições no primeiro turno (exceção do estado de Goiás). Para se analisar a validade da hipótese da relação entre eleições e percepção de risco eleitoral, foi realizado um teste de Qui-quadrado ( 2 × 2), com duas variáveis: Assinatura de Contrato $(0=$ antes das eleiçôes e $1=$ depois das eleições) e Risco Eleitoral. ${ }^{34}$

O resultado do Teste de Fisher demonstra que há associação entre Risco Eleitoral e data da Assinatura do Contrato ( $p$-value $=0,034)$. Um governador que acreditasse estar em posição de incerteza ou risco, tenderia a assinar o contrato com o governo federal e receber os recursos do BNDES para aplicação em seu estado, o que deveria produzir uma melhora na posição eleitoral.

Quais as motivações de um governo escolher ou não sanear um banco estadual? A principal razão é a capacidade, ou falta dela, do governo estadual de levantar as contrapartidas exigidas pelo governo federal, ou não (assumir 50\% da dívida, sendo que $20 \%$ deste total, à vista em ativos), e esta impossibilidade é derivada também da alta fragmentação no Poder Legislativo. No caso de não possibilidade de saneamento da instituição financeira, quais variáveis explicariam as outras escolhas: privatizado pelo controle do estado, privatizado/federalizado ou extinto?

Para explicar os motivos que implicaram nas escolhas, é preciso introduzir um novo procedimento de análise estatística, ${ }^{35}$ e em face das quatro opções inseridas no Proes, é necessária a adoção de um modelo de escolha múltipla, método que se baseia em uma distribuição de probabilidade entre as alternativas e suas utilidades esperadas.

Partindo das escolhas existentes no Proes, construímos uma variável dependente categórica

Tabela 1

Teste de Qui-quadrado: Risco Eleitoral versus Assinatura de Contrato

\begin{tabular}{llllll}
\hline & Valor & GL & $\begin{array}{l}\text { Significante } \\
\text { (duas caudas) }\end{array}$ & $\begin{array}{l}\text { Significante } \\
\text { (duas caudas) }\end{array}$ & $\begin{array}{l}\text { Significante } \\
\text { (uma cauda) }\end{array}$ \\
\hline Qui-Quadrado (Pearson) & 8,746 & 1 & 0,003 & - & - \\
\hline Correção de Continuidade & 4,156, & 1 & 0,042 & - & - \\
\hline Razão de Verossimilhança & 6,052 & 1 & 0,014 & - & - \\
\hline Teste de Ficher & - & - & - & 0,034 & 0,034 \\
\hline Associação Linear & 8,366 & 1 & 0,004 & - & - \\
\hline Número de casos válidos & 23 & - & - & - & - \\
\hline
\end{tabular}


(mudança de status quo), com o seguinte ordenamento: 1) extinto/liquidado; ${ }^{36}$ 2) privatizado/federalizado; 3) privatizado pelo Estado; e 4) saneado. Estas significam a perda gradativa do controle do estado sobre a instituição ou o processo de privatização/extinção, do último ao primeiro. $\mathrm{O}$ modelo estatístico a ser utilizado é uma Regressão Multinomial Ordenada (distribuição Probit).

As variáveis independentes categóricas são (dummies): "Agência de Fomento", "Raet" (se esteve alguma vez em regime de administração especial ou processo de liquidação extrajudicial entre 1983 a 1998), "mais de um banco comercial" (se possuía mais de um tipo de instituição financeira), "esquerda, direita, centro", "apoia o presidente da República" e "continuação" (se o governador eleito em 1994 é continuação da administração anterior). As variáveis numéricas são: "receita tributária própria por receita corrente líquida", "resultado primário por receita corrente líquida”, "número de votantes em relação ao eleitorado", "taxa de fragmentação", "despesa de pessoal” e número de partidos", "porcentagem de ca- deiras que a coligação do governador obteve na Assembleia Legislativa”, "porcentagem de cadeiras ocupadas por partidos de esquerda”. O espaço temporal do painel vai de 1995 a 1998.

A estratégia metodológica foi a seguinte: serão executados quatro modelos. No primeiro serão analisadas as variáveis categóricas ligadas diretamente à questão dos bancos estaduais ("agências de fomento", "Raet" e "mais de um banco"); no segundo, introduziremos variáveis de desempenho fiscal ("receita tributária própria por receita corrente líquida", "resultado primário por receita corrente líquida" e "despesa de pessoal"); no terceiro modelo serão introduzidas variáveis políticas ("taxa de fragmentação", "número efetivo de partidos", "porcentagem de cadeiras que a coligação do governador obteve na Assembleia Legislativa" e "porcentagem de cadeiras ocupadas por partidos de esquerda"); e no quarto modelo serão introduzidas as dummies referentes à ideologia e apresentados os coeficientes.

A leitura dos modelos multinomiais ordenados é simples, a saber, o sinal positivo indica que a variá-

Tabela 2

Regressão Multinomial Ordenada (Probit)

\begin{tabular}{|c|c|c|c|c|}
\hline Variáveis & Modelo 1 & Modelo 2 & Modelo 3 & Modelo 4 \\
\hline Agências de Fomento & $-1,165506 * * * *$ & $-1,296098 * * * *$ & $-1,50667 * * * *$ & $-1,514607 * * *$ \\
\hline Raet & $-1,939137 * * * *$ & $-2,087974 * * *$ & $-2,739722 * * * *$ & $-2,915716^{* * * *}$ \\
\hline Mais de Um Banco Comercial & $0,6638768 * * *$ & $0,6802851^{* * * *}$ & $0,7497429 * * * *$ & 0,8406446 **** \\
\hline Receita Tributária Própria & - & 0,0036361 & $-0,0009449$ & 0,0013686 \\
\hline Resultado Primário & - & $-0,04125$ & 0,0069112 & $-0,058893$ \\
\hline Despesa de Pessoal & - & $-0,01877738$ & $-0,0333696^{* * * *}$ & $-0,0359603^{* * * *}$ \\
\hline Votantes & - & - & $0,0550236 * * *$ & $0,05500212^{* * * *}$ \\
\hline Apoia o Presidente & - & - & $-1,365234^{* * * *}$ & $-1,337934^{* * * *}$ \\
\hline Taxa de Fragmentação & - & - & $4,429164 *$ & 1,260208 \\
\hline Número Efetivo de Partidos & - & - & $-0,1437199 *$ & $-0,0730243$ \\
\hline Cadeiras Coligação do Governador-\% & - & - & $0,0227564 *$ & 0,0091993 \\
\hline Cadeiras de Partidos de Esquerda -\% & - & - & $0,0714315^{* * * *}$ & $0,0780608 * * * *$ \\
\hline Continuação & - & - & $0,5372249 * *$ & $0,7505873^{* * * *}$ \\
\hline Esquerda & - & - & - & Dropped \\
\hline Direita & - & - & - & $-0,246064$ \\
\hline Centro & - & - & - & $-0,782441 * *$ \\
\hline Pseudo R2 & 0,2256 & 0,2502 & 0,3792 & 0,3863 \\
\hline
\end{tabular}

Estados omitidos.

Significante $\mathrm{a}^{* * *} 1 \%$, $* * 5 \% * 10 \%$. 
vel influencia a escolha do governo estadual na direção do que racionalmente deveria ser sua primeira preferência (saneamento). O sinal negativo indica o contrário, que a variável afasta o ente subnacional da sua primeira preferência, aproximando-o daquela pertencente ao Executivo federal (extinção). Os governadores possuíam como primeira preferência manter os bancos estaduais sobre o controle dos governos, contudo a negociação com o governo central, as dificuldades econômicas e as eleiçōes alteraram a posição do ranking de preferência do Executivo estadual.

Os Probits desenvolvidos demonstram que as principais variáveis explicativas para o aceite das regras do Proes pelos estados, e consequentemente mudança do status quo nas relaçōes federativas, foram "agências de fomento", "Raet", "despesa de pessoal", "apoia o presidente" e o "governador pertencer a partido político de centro" (sinais negativos). ${ }^{37}$ Desta forma, um estado que tenha negociado a constituição de uma instituição não financeira de fomento teve o banco estadual sob administração especial no período, o governador pertencia a partido político que apoiava o presidente no Congresso Nacional (ideologicamente de centro), com alta despesa de pessoal em relação à receita corrente, tenderia a aceitar liquidar a instituição ou privatizá-la. No caso das duas primeiras variáveis, estas também fazem parte das conclusōes de Beck, Crivelli e Sumerhill (2003), as outras não. ${ }^{38}$

Os modelos demonstraram que, no caso da unidade subnacional possuir mais de um banco comercial estadual, esta teria a tendência de sacrificar uma instituição e sanear a outra.

Todas as variáveis introduzidas no modelo 3 da regressão apresentaram valor de $p$ significantes. Como os contratos do Proes exigiam a anuência do parlamento estadual, variáveis que medem a desagregação parlamentar e partidária são importantes para percebermos como a distribuição interna das forças políticas das Assembleias Legislativas podem ter impactado no processo. "Taxa de fragmentação" e "número efetivo de partidos" apresentaram sinais contrários. A primeira indica que maior fragmentação partidária poderia tornar mais difícil para o governo estadual chegar a um acordo nos termos da principal escolha da União (extinção).
Número efetivo de partidos indicaria o contrário, quanto maior o percentual de cadeiras ocupadas por diferentes legendas partidárias, mais fácil deveria ser para o governador conseguir a aprovação do acordo com os legisladores. A variável "porcentagem de cadeiras" que a coligação do governador obteve na Assembleia Legislativa apresentou sinal positivo, indicando que, quanto maior a base de apoio parlamentar eleita pelo governo local, mais improvável o governador conseguir uma acordo com a União para a extinção ou liquidação das instituiçōes bancárias. Contudo, deve-se observar que os coeficientes destas duas últimas variáveis são muito fracos, $\operatorname{com} p$ valor a $10 \%$. No modelo 4 , quando foram introduzidas as variáveis representativas da ideologia partido do governador, todas perderam significância estatística.

Duas variáveis deste conjunto merecem destaque: "porcentagem de partido de esquerda na Assembleia Legislativa" e "se o governo é continuidade do anterior". Ambas apresentaram valores de $p<$ $0.5 \%$ e sinais positivos nos modelos 3 e 4 . A primeira indica que, um maior número de parlamentares de partido de esquerda dificultava a assinatura de um acordo com a União, centrado nas preferências deste último, o que vai de acordo com a lógica das teorias institucionalistas. A segunda indica que, se o governo era continuidade do anterior, a tendência era de realizar escolhas mais próximas das preferências dos governadores de estado, como privatização pelo controle do governo estadual ou saneamento.

No fim, o processo de redução chegou aos termos desejados pelo governo federal. O sistema financeiro público estadual foi reduzido a menos de um quinto do que era quando Fernando Henrique Cardoso assumiu o poder. Os estados tinham sob seu controle, em 1994, 33 instituições financeiras entre bancos, caixas e instituições de desenvolvimento. Em três anos de extensas negociações, o governo federal conseguiu uma renegociação de dívidas com regras de punições críveis e extinguiu quase que completamente o setor financeiro público estadual. Nunca, na história do Brasil, houve em períodos democráticos, tamanha mudança no status quo das relações federativas em tão pouco tempo. 


\section{Conclusão}

Em ciência política é comum se falar de ganhadores e perdedores. Contudo, muitas vezes esta relação não pode ser completamente compreendida ou deve ser relativizada. No interior das relaçōes federativas, parecenos que a barganha trouxe perdas e ganhos a todos. Certamente, em termos de accountability, da previsibilidade do crescimento da dívida pública e da estabilidade econômica, o processo de redução da atividade bancária dos estados foi uma vitória, mas a que custo? O volume de títulos federais emitidos no âmbito do Proes foi de 61 bilhōes e quatrocentos milhões de reais, mais de $100 \%$ de toda ajuda federal anteriormente realizada para salvamento destas instituiçōes financeiras. ${ }^{39}$

Mesmo concordando com conclusões que enfatizam que o processo significou uma vitória do governo federal, como as de Garman, Silva e Marques (1998) e Kerches (2001), há necessidade de relativizá-las. No jogo, claramente não houve uma imposição de preferências, mas uma ampla negociação, em que elementos-chaves levaram os estados a trocar o controle de suas instituiçóes pelos amplos refinanciamentos de dívidas oferecidas pelo governo federal. $\mathrm{O}$ volume dos novos empréstimos, a permissão de os estados constituírem Agências de Fomento, a percepção que o sucesso do Plano Real dependia do controle do gasto público estadual, a proximidade com o governo federal, o ciclo político, a permissão da reeleição para os cargos executivos e a percepção do risco eleitoral foram elementos inerentes ao processo.

$\mathrm{O}$ processo de redução da atividade bancária permitiu a centralização do poder de "monopólio de emissão de moeda" nas mãos do Banco Central. Ao governo federal garantiu um maior controle da dívida pública e aos estados, um forte alívio imediato de caixa e recursos para serem gastos durante o período eleitoral. Dos governadores de estado que disputaram um novo mandato ou apoiaram correligionários, $60 \%$ conseguiram seu intento.

\section{Notas}

1 Abrucio (2002); Abrucio e Costa (1999); Abrucio e Samuels (1997); Ames (2003); Mainwaring (1991 e 1999), Samuels (2003) e Regis (2009).
2 Amorim Neto denomina esta visão de pessimista e defende que é principalmente consequência do espaço temporal onde foram desenvolvidas estas análises. "[...] os principais observadores da primeira década do Brasil pós-autoritário descreveram os seus partidos, na sua maioria, como indisciplinados e disfuncionais, mesmo para os padróes latino-americanos e, por isso, seriamente danosos para uma efetiva governabilidade, a consolidação democrática e a reforma economica do país" (2006, p. 127).

3 Esta afirmação é fortemente contestada por Meneghello que, ao analisar a importância dos partidos políticos e a formação dos gabinetes presidenciais no Brasil entre 1985 a 1997, afirma: "[...] os partidos exercem papel central na organização e funcionamento do poder executivo. O estudo dos governos do período demonstrou que a dinâmica de coalizões partidárias, compostas pelas maiores agremiações no Congresso e caracterizadas por um significativo grau de coerência ideológica, constitui a fórmula dominante para a sua organização e é um aspecto fundamental das relações entre o Executivo e o Legislativo" (1998, p. 165, grifos no original).

4 De acordo com esta análise, em regimes democráticos em que os partidos políticos nacionais são controlados por lideranças regionais, que por sua posição institucional também dominam o Poder Legislativo, os parlamentares têm como foco atuações paroquiais, em detrimento das questões públicas nacionais. Os partidos políticos também são fracos, pois as carreiras dos parlamentares não dependem da estrutura partidária, mas sim da obtenção de recursos e benefícios para sua base eleitoral. Para Amorim Neto e Santos, “o Brasil é um dos mais notáveis exemplos de segredo ineficiente" (2003, p. 663).

5 Para uma análise da discussão sobre federalismo e representação política no Brasil, ver Tavares de Almeida (2001, pp. 16-20).

6 A argumentação básica de que o sistema político brasileiro não funciona ou funciona muito mal foi contestada por Argelina Figueiredo e Fernando Limongi (2001) Estes afirmam que, apesar da estrutura institucional estabelecida pela Constituição de 1998 ser a mesma do período anterior ao golpe militar, isto não significa que o funcionamento do sistema político brasileiro siga o padrão anterior. A partir da análise do processo de tomada de decisão do parlamento brasileiro, Figueiredo e Limongi identificam mecanismos internos de funcionamento do Congresso Nacional que, em sua avaliação, invalidam boa parte da argumentação do grupo anterior. "Os dados não se harmo- 
nizam com a visão segundo a qual a presidência só vê seus projetos aprovados após extenuantes e custosas negociações, com maiorias formadas caso a caso na base da troca clientelista individual. Para que tal fosse verdade, o tempo de tramitação de seus projetos deveria ser muito maior e a taxa de aprovação não poderia ser assim tão alta. Se há crise de governabilidade, é hora de procurarmos outros suspeitos. As evidências reunidas pedem a liberação do réu, detido indevidamente e sem culpa formada" (Figueiredo e Limongi, 2001, p. 69). Amorim Neto (2006) denomina esta perspectiva de análise como otimista.

7 Tavares de Almeida afirma que "do ponto de vista das relações intergovernamentais, a federação brasileira é um arranjo complexo em que convivem tendências centralizadoras e descentralizadoras, impulsionadas por diferentes forças, com motivaçōes diversas, produzindo resultados variados" (2001, p. 29).

8 O Relatório de Atividades do Departamento de Operaçôes Bancárias do Bacen de 1984 coloca que, de acordo com a legislação vigente da época, a autoridade monetária poderia intervir e/ou liquidar os bancos estaduais que demonstrassem dificuldades crônicas de liquidez. Contudo, também percebia que isto não era possível de ser realizado, tanto por causa da questão política como pelos perigos possíveis de crise sistêmica, causada pela possível perda de confiança do público no sistema bancário. Aparentemente a burocracia do Banco Central e sua diretoria tinham posiçôes divergentes sobre a capacidade legal da instituição de agir. O arcabouço jurídico (lei 6024/1974) à disposição do Bacen era claro, qualquer banco privado ou público não federal poderia sofrer intervenção ou ser liquidado ex-officio, desde que violasse as práticas de boa gestão bancária. "O curioso do quadro então vigente era que o Banco Central, embora dispondo de ordenamento legal que lhe permitisse intervir e liquidar instituições de crédito oficial, ficava tolbido em sua ação porque não poderia desconhecer as consequências traumáticas da aplicação pura e simples do mecanismo criado pela Lei no 6.024, de 13.03.74, quer no campo politico-institucional, quer no âmbito dos sistemas financeiro e do mercado de capitais, pelo rompimento do salutar e primordial princípio da fé pública" (Bacen, 1984 , p. 5, grifo meu).

9 Também faziam parte sete bancos de desenvolvimento.

10 Segundo Kerches, no segundo semestre de 1994 o Senado tomou decisões que agravaram a situação fiscal dos estados, e consequentemente dos bancos. Desde 1975 os senadores haviam emitido quatro resoluçōes sobre endividamento dos estados (62/75, 93/76,
94/89 e 58/90), nenhuma foi completamente obedecida. No caso da resolução 11/94, o problema era que esta "determinava que o limite de comprometimento de receita, descontados os pagamentos de FGTS, de parte da dívida externa e de dívidas renegociadas por força de lei, o saldo deve ser usado no resgate de títulos da dívida mobiliária. Do ano de 1995 em diante, esse limite de comprometimento foi de $9 \%$ da receita líquida. O percentual de rolagem resultante da aplicação de tais critérios seria calculado pelo Banco Central e fornecido ao Senado. Contudo, os parlamentares permitiam a rolagem de $100 \%$ dos títulos da dívida mobiliária de estados e municípios. A rolagem de tudo o que vencia incluía juros reais (além da inflação). Assim, quando o Senado aprovava a rolagem de $100 \%$ dos títulos, estava sancionando, na prática, o aumento das dívidas" (Kerches, 2001, p. 100).

11 De acordo com Gustavo Franco, a ideia de que uma intervenção em um banco estadual pequeno é "mais fácil" do que em um grande é enganosa. "É sempre fácil, em tese, fazer uma intervenção no banco de Sergipe ou de Alagoas, porque são pequenininhos; mas politicamente é sempre um problema, porque eles sempre vão perguntar: "São Paulo está tendo o mesmo tratamento? Tendo em vista que o Banespa está fazendo igual a nós, vocês vão fazer a mesma coisa em São Paulo?” Se o programa federal não tratasse São Paulo da mesma forma, não se conseguiria fazer nem em Alagoas, nem em Rondônia, nem em lugar nenhum" (Disponível em <http:// www.econ.puc-rio.br/gfranco/CPDOCMario\%20Covas.htm>, acessado em março de 2009).

12 O conceito de Resultado Primário (RP) utilizado foi estabelecido pela Portaria no 089/97 do Ministério da Fazenda: receitas arrecadadas (RA), menos receitas financeiras (RF), operações de crédito (OC) e alienação de bens $(\mathrm{AB})$, subtraído das despesas liquidadas (DL) e restos a pagar, excluídas as contas de serviços das dívidas (SD) mobiliária e contratual. Em termos matemáticos pode ser representada pela fórmula: $\mathrm{RP}$ $=\mathrm{RA}-(\mathrm{RF}+\mathrm{OC}+\mathrm{AB})-(\mathrm{DL}+\mathrm{NP}-\mathrm{SD})$.

13 O banco Itaú comprou o Banerj por 300 milhões de reais, o que significa que o governo do estado do Rio de Janeiro ainda teve de cobrir 50 milhões do passivo do Previ-Banerj. Além disso, para viabilizar a privatização do banco carioca o Bacen permitiu ao novo controlador não "cumprir as exigências de aplicação mínima em habitação, hoje, de $70 \%$ de recursos da caderneta de poupança” (Ouriques, 1998, p. 115).

14 Disponível em <http://alerjln1.alerj.rj.gov.br/constest. nsf/PageConsEst?OpenPage> e no Diário da Justiça, de 9/5/1997. 
15 Em reportagem a revista Veja de 22 de março de 1995, os jornalistas Angélica Santa Cruz e Felipe Partury analisaram o relatório do Bacen sobre o Banespa, e observam que "a cratera encontrada é do tamanho de 21 bilhôes de reais, vinte vezes mais do que o rombo que levou a falência o Baring, uma instituição com mais de 200 anos de tradição na Inglaterra”.

16 Revista Veja, 26/7/1995.

17 Gustavo Franco, no entanto, defende que a diferença entre os dois governadores tenha ocorrido mais por questôes de psicologia individual. "Vale a pena sempre colocar essas duas situações em paralelo. Politicamente, tinham um peso semelhante, mas o governo do Rio teve uma postura totalmente diferente. O governador eleito do Rio, Marcelo Alencar, olhou para o Banerj e disse: "Caramba! Temos aqui um banco que perde 40 milhões por mês. Eu não quero isso; se a União quiser, por favor, leve e resolva." Já em São Paulo, a situação era totalmente diferente, porque prevalecia esta irritação, a meu juízo sem razão, pela forma da intervenção, sem consulta ou negociação. Enfim, vou abster-me de comentar sobre isso. Ao passo que no Rio houve uma postura mais pragmática e mais matemática, talvez" (Disponível em <http://www. econ.puc-rio.br/gfranco/CPDOCMario\%20Covas. htm>, acessado em março de 2009).

18 O instituto das Medidas Provisórias dava ao governo federal uma enorme margem de manobra nas negociações. Como eram necessárias várias reedições até sua aprovação final pelo Congresso Nacional, o Executivo federal aproveitava este momento para adequar a norma às vicissitudes da negociação. A MP 1514 foi reeditada 69 vezes até se tornar a Lei n. ${ }^{\circ}$ 2192-70, em 24 de agosto de 2001. Comparando a primeira edição da Medida Provisória com algumas reedições do final de 1998 e início de 1999, disponíveis no site da presidência da República, foram observados o adendo de regras que detalham a forma de pagamento do empréstimo, taxa de juros, garantias e contragarantias (como a utilização de títulos dos tesouros estaduais e órgãos da administração direta dos estados).

19 Dos estados que possuiam bancos comerciais e de desenvolvimento, dois não participaram do Proes: Brasília e Paraíba.

20 "Art. $1^{\circ}$ Fica a União, no âmbito do Programa de Apoio à Reestruturação e ao Ajuste Fiscal dos Estados autorizada, até 31 de março de 1998 a: I - assumir a dívida pública mobiliária dos estados e do Distrito Federal, bem como, ao exclusivo critério do Poder Executivo Federal, outras obrigações decorrentes de operaçôes de crédito interno e externo, ou de natureza contratual, relativas a despesas de investimentos, líquidas e certas, exigíveis até 31 de dezembro de 1994; II - assumir os empréstimos tomados pelos estados e pelo Distrito Federal junto à Caixa Econômica Federal, com amparo na Resolução no 70, de 5 de dezembro de 1995, do Senado Federal; III - compensar, ao exclusivo critério do Ministério da Fazenda, os créditos então assumidos com eventuais créditos de natureza contratual, líquidos, certos e exigíveis, detidos pelas unidades da Federação contra a União; IV - refinanciar os créditos decorrentes da assunção a que se refere o inciso I, juntamente com créditos titulados pela União contra as unidades da Federação, estes a exclusivo critério do Ministério da Fazenda $₫ 1^{\circ}$ As dívidas de que trata o inciso I são aquelas constituídas até 31 de março de 1996 e as que, constituídas após essa data, consubstanciam simples rolagem de dívidas anteriores".

21 As regras do acordo eram excelentes para os estados, em vista do impacto que a dívida mobiliária teria sobre as contas estaduais, tão bom que "alguns poucos estados deverão quitar seus compromissos com a União em 15 anos ao invés de 30 estabelecidos na maioria dos contratos (casos do Piauí, Rio Grande do Norte e Ceará)" (Mora, 2002, p. 25). Mesmo que as regras do acordo fossem excelentes para os estados, não agradaram a todos. O senador Luiz Estevão, através do Projeto de Lei $00014 / 1999$, tentou alterar o artigo $1^{\circ}$ da Lei 9496/97, reabrindo o prazo de renegociação das dívidas dos estados e do Distrito Federal junto à União. Em 24/5/2001, o projeto foi arquivado pela Comissão de Assuntos Econômicos (CAE), com parecer contrário de Romero Jucá, líder do governo no Senado.

22 Para os estados, o equacionamento da dívida não depende exclusivamente de medidas de restrições de gastos. O crescimento da economia "é condição sine qua non para assegurar a sustentabilidade da dívida estadual de longo prazo" (Mora, 2002, p. 65). Para conseguir melhor situação fiscal no final do ano, vários estados iniciaram um processo de aumento das alíquotas de impostos estaduais, como "o Rio Grande do Sul, que elevou a tarifa do ICMS para pagar salários" (O Estado de São Paulo, 30/7/1997).

23 Padrão e Caetano afirmam que no segundo semestre de 1996 todos os governadores de estado se reuniram para discutir qual "a melhor forma de pressionar o governo federal, pois só poderia vir de lá um alivio para o aperto de caixa. [...] A pressão dos governadores sobre o governo federal para uma rolagem camarada das dívidas financeiras tinha tudo para dar certo. Mas o movimento foi atropelado por um fato político que 
desmoralizou a atuação dos governadores. Muitos deles, esmagados pelo peso da falência pública, já haviam cedido às tentações da ilegalidade. Aliaram-se a sinistros personagens do mercado financeiro em busca de solução milagrosa. E foram flagrados com a abertura da CPI dos Precatórios" (1997, p. 26).

24 "Não seria um exagero descrever esta "crise sistêmica" dos Estados como "falência financeira do sistema federativo": todos os estados quebraram, juntamente com seus bancos estaduais e a maior parte de suas empresas" (O Estado de São Paulo, 15/9/2002).

25 A partir de 1995 o número de greves no serviço público aumentou especialmente na esfera estadual. De acordo com Índice do Boletim Dieese, de abril de 1997, analisando o ano anterior, "o funcionalismo estadual, por sua vez, realizou 114 greves, ou seja, um volume que representa $9,06 \%$ das greves ocorridas em todo o Brasil. Essas greves envolveram 386.112 trabalhadores, um total elevado, que resulta em alto número médio de grevistas -3.387 trabalhadores parados por greve. Tais números levaram o setor a ter uma alta participação no percentual de trabalhadores - hora parados, com $18,17 \%$ do total de greves em todo o Brasil (inclusive as do setor privado). Em termos de duração média, os servidores estaduais foram aqueles com greves mais longas - em média, 13,5 dias" (grifos meus).

26 Couto e Abrucio afirmam que o processo de privatização das instituições financeiras dos governos subnacionais "deve ser compreendido à luz da renegociação das dívidas estaduais [...]" (2003, p. 278).

27 Caso o governo estadual não tivesse como dispor dos $50 \%$ para pagamento à vista, o contrato de refinanciamento iria prever a entrega, "pela Unidade da Federação, de ativos privatizáveis, aceitos pela União, em montante equivalente a, no mínimo, cinquenta por cento do total refinanciado, para fins de posterior amortização" (Parágrafo Único, Artigo 8 da Lei 2192-70).

28 Como se verá mais adiante, as eleições de 1998 foram um elemento-chave no processo de privatização dos bancos estaduais. $\mathrm{O}$ instituto da reeleição para os cargos executivos alterou profundamente o funcionamento da política dos estados, os governadores seriam candidatos natos à disputa, e era do interesse destes conseguir o melhor acordo possível antes das eleições, pois isso aliviaria profundamente o caixa dos estados e ainda permitiria aos governos receberem aportes financeiros do Banco Nacional de Desenvolvimento Econômico e Social (BNDES), decorrentes "de recursos em antecipação às receitas futuras dos leilōes de privatização" (Melo, 2005, p. 857).
29 "O prazo para a renegociação de dívidas encerra no dia 31/3, mas haverá prorrogações, na base do caso-a-caso, para garantir que todos os estados regularizem suas contas" (disponível em <http://www.fazenda.gov. br/portugues/releases/1998/r980330.asp>, acessado em outubro de 2007).

30 Originalmente, o acordo do governo federal com o estado de Santa Catarina para federalização e a privatização foi realizado em março de 1998. Contudo, ao assumir o poder, Esperidião Amin anulou a assembleia de acionistas do Besc realizada em 20/3/1998, zerando o jogo e obrigando a União a uma nova rodada de negociações.

31 "O presidente Fernando Henrique Cardoso se comprometeu a federalizar uma dívida de cerca de $\mathrm{R} \$ 630$ milhōes do governo catarinense. Na prática, a operação será feita para compensar a exclusão de títulos irregulares do Estado da rolagem de cerca de R $\$ 2$ bilhôes aprovada ontem pelo Senado. Pelo projeto aprovado, a União refinanciará por um prazo de dez anos as dívidas dos Estados e municípios que emitiram títulos irregularmente para pagar precatórios (dívidas resultantes de decisões judiciais). O governo federal fará depósitos em juízo no valor das dívidas até que a Justiça decida sobre a validade ou não dos títulos. Parte dos títulos de Santa Catarina, no valor de R\$ 560 milhões, não foi incluída no projeto porque os papéis, apesar de emitidos, não chegaram ao mercado. $\mathrm{O}$ governador Esperidião Amin (PPB), com o apoio do presidente do PFL, senador Jorge Bornhausen (SC), pretendia rolar até a dívida referente aos títulos não negociados - que, na prática, não existia. $\mathrm{O}$ dinheiro obtido da União seria usado para pagar uma dívida com o Ipesc, instituto de previdência dos servidores catarinenses. A intenção de Amin e Bornhausen foi barrada pelo líder do PMDB no Senado, Jader Barbalho (PA), que aprovou uma emenda excluindo os títulos não negociados da operação de rolagem. O governador catarinense conseguiu uma compensação em reunião com FHC, na última quinta-feira. Em vez de rolar os títulos, o governador obteve a promessa de federalização de sua própria dívida com o Ipesc. Também participaram do encontro o ministro Pedro Malan (Fazenda) e o presidente do Banco Central, Armínio Fraga, além de Bornhausen. Pelo acordo, a União assumirá a dívida de cerca de R $\$ 630$ milhões do governo catarinense com o Ipesc e cobrará o empréstimo em dez anos" (Zero Hora, 5/8/1999).

32 Marconi Perillo (PSDB), governador eleito em 1998, em substituição a Maguito Vilela (PSDB), afirma que " quando o Beg fechou, propus a criação de uma agên- 
cia de fomento para substituí-lo. O ministro Pedro Malan - que, por sinal, tratou muito bem Goiás - aceitou a proposta, mas ofereceu apenas 4 milhōes de reais para capitalizar a agência. Bati a mão na mesa e não aceitei - queria 70 milhôes de reais. Acabei convencendo o ministro. Então, o governo federal entrou com 60 milhôes e nós entramos com 10 milhões e criamos a Agência de Fomento, que tem sido um instrumento importante para o desenvolvimento de Goiás" (disponível em <http://www.jornalopcao2.com.br/index. asp?secao $=$ Manchete\&idjornal=77>, acessado em outubro de 2007).

33 Segundo Kerches, este também é o caso do Maranhão, que "pretendia manter o banco sob seu controle após o saneamento. Entretanto, as garantias exigidas pelo Banco Central acabaram inviabilizando este tipo de operação" (2001, p. 160).

34 O risco eleitoral foi medido com base na análise das primeiras pesquisas de intenção de voto (voto estimulado) apresentadas pelos institutos Ibope, DataFolha e Brasmarket para o ano de 1998. O risco eleitoral será medido da seguinte forma: a) Risco Eleitoral Baixo e Médio do governador perder a eleição (ou o candidato que apoia) $=+20 \%$ a $10 \%$ de votos sobre o segundo colocado; e b) incerteza e risco de perder $=+$ 9 a $-20 \%$ de votos abaixo do primeiro colocado.

35 Este teste é fortemente inspirado em Beck, Crivelli e Sumerhill (2003).

36 As poucas instituições transformadas diretamente em Agências de Fomento foram colocadas nesta categoria. O governo federal ainda negociou a constituição de pelo menos mais doze instituições deste tipo entre os estados.

37 Teste de Qui-Quadrado de Independência demonstra que existe forte associação entre Partido de Centro e Apoio ao Presidente. Fisher's Exact Test $=0,000$.

38 Ao contrário do que afirmam Beck, Crivelli e Sumerhill (2003), a dependência de transferências federais constitucionais - estados da região Norte, Nordeste e Centro-Oeste - não apresentou qualquer sinal significativo.

39 Franco (2000) calcula que os ajustes anteriores ao Proes chegaram a 42 bilhões de reais, o que perfaz um total em ajuda federal de 103 bilhões a partir de 1983.

\section{BIBLIOGRAFIA}

ABRANCHES, Sérgio H. (1988), "Presidencialismo de coalizão: o dilema institucional brasileiro". Dados, 1 (21): 5-33.
(1988), "Presidencialismo de coalizão e crise de governança. Porto Alegre, trabalho apresentado no Seminário "O Sistema Partidário na Consolidação da Democracia Brasileira”, em 22 e 23 de outubro de 2001.

ABRUCIO, Fernando L. (2002), Os baröes da federação: os governadores e a redemocratização brasileira. 2 ed. São Paulo, Hucitec.

ABRUCIO, Fernando L. \& COSTA, Valeriano M. (1999), Reforma do Estado e o contexto federativo brasileiro. São Paulo, Konrad-Adenauer.

ABRUCIO, Fernando L. e SAMUELS, David. (1997), “A 'nova' política dos governadores: política subnacional e transição democrática no Brasil”. Lua Nova, 40/41: 137-16.

AMES, Barry. (2003), Os entraves da democracia no Brasil. Rio de Janeiro, Editora da FGV.

AMORIM NETO, Octavio. (2006), Presidencialismo e governabilidade nas Américas. Rio de Janeiro, Editora da FGV/Konrad-Adenauer.

AMORIM NETO, Octavio e SANTOS, Fabiano, (2003), "O Segredo Ineficiente Revisto: O que propóem e aprovam os deputados brasileiros". Dados - Revista de Ciências Socais, Rio de Janeiro, v. 46, n-04, pp.661- 698

BACEN. (1984), "Relatório de atividades bancárias". Brasília, Banco Central do Brasil.

BECK, Thorsten; CRIVELLI, Juan \& SUMMERHILL, William. (2003), "State bank transformation in Brazil: choices and consequences". Trabalho apresentado na Conference on Bank Privatization, World Bank.

CARDOSO, Fernando H. (2006), A arte da politica: a história que vivi. Rio de Janeiro, Civilização Brasileira.

COUTO, Cláudio \& ABRUCIO, Fernando (2003), 'O segundo governo FHC: coalizōes, agendas e instituições'. Tempo Social, 15 (2), pp. 269-301.

FIGUEIREDO, Argelina e LIMONGI, Fernando (2001), Executivo e Legislativo na Nova Ordem Constitucional. Rio de Janeiro: FGV Editora.

FRANCO, Gustavo. (2000), O desafio brasileiro: ensaios sobre desenvolvimento, globalização e moeda. São Paulo, Editora 34.

GARMAN, Christopher; LEITE, Cristiane e MARQUES, Moisés. "Impactos das relações Banco 
Central x Bancos Estaduais no arranjo federativo brasileiro pós-1994 - Análise a luz do caso Banespa”. Revista de Economia Politica, São Paulo, v. 21, no 1 (81), p. 40-61, jan-mar, 2001.

LEAL, Luis O. (2000), O Proes e a eficiência dos bancos estaduais. Rio de Janeiro, dissertação de mestrado em Economia, PUC/RJ.

KERCHES, Cristina. (2001), Autoridade monetária e federalismo no Brasil: uma reflexão sobre a reforma do sistema de bancos públicos estaduais. São Paulo, dissertação de mestrado em Ciência Política, FFLCH-USP.

MAINWARING, Scott. (1991), "Políticos, partidos e sistemas eleitorais: o Brasil numa perspectiva comparativa". Novos Estudos Cebrap, 29: 34-58.

(1999), Rethinking party systems in the third wave of democratization: the case of Brazil. Stanford, Stanford University Press.

MARKLER, Harry M. (2000), "Bank transformation and privatization in Brazil: financial federalism and some lessons about bank prizatization". The Quarterly Review of Economics and Finance, 40: 45-69.

MELO, Marcus André. (2002), "Estado, governo e políticas públicas", in Sergio Miceli (org.), $O$ que ler na ciência social brasileira (politica). Brasília/São Paulo, Sumaré/Capes.

. (2005), "O sucesso inesperado das reformas de segunda geração: federalismo, reformas constitucionais e política social". Dados, 48 (4): 845-889.

MENEGHELLO, Rachel. (1998), Partidos e governo no Brasil contemporâneo (1985-1997). São Paulo, Paz e Terra.

MORA, Mônica. (2002), "Federalismo e dívida estadual no Brasil". Rio de Janeiro, Ipea (Texto para Discussão no 866).

PAES, Julieda P. (1996), Bancos estaduais, "criação" de moeda e ciclo político. São Paulo, dissertação de mestrado em Economia, Fundação Getulio Vargas.

OURIQUES, Nildo D. (1998), "A sedução revolucionária e o Plano Real", in Nildo Ouriques e Waldir J. Rampinelli, No fio da navalha: crítica das reformas neoliberais de FHC, 2 ed., São Paulo, Xamã.
PADRÃO, Ana P. \& CAETANO, Valderez. (1997), O segredo do cofre: como os estados brasileiros chegaram ao rombo de mais de $R \$ 100$ bilhões. São Paulo, Globo.

REGIS, André. (2009), O novo federalismo brasileiro. Rio de Janeiro, Forense.

RODDEN, Jonnathan. (2003), "Federalism and bailouts in Brasil", in Jonnathan Rodden; Gunnar Eskeland e Jennie Livack (orgs.), Fiscal decentralization and the challenge of hard budget constraints. Cambridge, The MIT Press.

SAMUELS, David. (2003), Ambition, federalism and legislative politics in Brazil. Cambridge, Cambridge University Press.

SHUGART, Mattew \& CAREY, John. (1992), Presidents and assemblies: constitutional design and electoral dynamics. Cambridge, Cambridge University Press.

SOLA, Lourdes \& KUGELMAS, Eduardo. (2002), "Estabilidade econômica e o Plano Real como construção política e democratização - statecraft, liberalização econômica", in Lourdes Sola; Eduardo Kugelmas e Laurence Whitehead (orgs.), Banco Central - autoridade politica e democratização: um equilíbrio delicado, Rio de Janeiro, Editora da FGV.

SOLA, Lourdes; GARMAN, Christopher \& MARQUES, Moisés. (2002), "Banco Central, autoridade política e governabilidade democrática" in Lourdes Sola; Eduardo Kugelmas e Laurence Whitehead (orgs.), Banco Central autoridade política e democratização: um equilíbrio delicado, Rio de Janeiro, Editora da FGV.

TAVARES DE ALMEIDA, Maria H. (2001), "Democracia e governo". Revista de Informação Bibliográfica em Ciências Sociais (BIB), 51: 13-34. 


\section{PLANO REAL, PRIVATIZAÇÃO DOS BANCOS ESTADUAIS E REE- LEIÇÃO}

\section{Ricardo Borges Gama Neto}

Palavras-chave: Federalismo brasileiro; Plano Real; Privatização; Reeleição; Governo Fernando Henrique Cardoso.

Este artigo procura explicar as transformações nas relações federativas, ocorridas no primeiro governo Fernando Henrique Cardoso. De acordo com a literatura do federalismo, durante o processo de redemocratização, os governadores de estado tornaram-se atores importantes, adquirindo extensos poderes de veto às ações do Executivo federal, especialmente às destinadas ao controle da crise econômica. Entretanto, o governo FHC foi capaz de estabilizar a economia e recentralizar parte das relaçóes federativas. Como isto foi possível? A hipótese deste trabalho é que as dificuldades trazidas pelo Plano Real, as regras das dívidas estaduais e a reeleição aos cargos executivos mudaram as preferências das elites políticas estaduais, tornando atrativa para os governadores de estado a privatização das instituições financeiras estaduais, o que, no final, permitiu ao governo federal recentralizar parte das relaçõoes federativas brasileiras

\section{REAL PLAN, PRIVATIZATION OF STATE BANKS, AND REELECTION}

\author{
Ricardo Borges Gama Neto
}

Keywords: Brazilian federalism; Real Plan; Privatization; Reelection; Fernando Henrique Cardoso.

This article attempts to explain the changes in Brazilian federative relations, occurred in the first government of Fernando Henrique Cardoso. According to the literature above federalism, during the process of democratization the state governors have become an important players, acquiring extensive power from veto points on the Federal Executive Branch, specially designed to control in case of economic crisis. However, the Cardoso government was able to stabilize the economy and recenter part of federative relations. How was this possible? The hypothesis of this study is that the difficulties brought by the Real Plan, the rules of the of state debts and re-election to executive positions, changed the preferences of state political elites, making it attractive to state governors for the privatization of state financial institutions which, in the end, allowed the federal government recenter part of the Brazilian federal relations.

\section{PLAN REAL, PRIVATISATION DES BANQUES DES ÉTATS ET RÉELECTION}

\author{
Ricardo Borges Gama Neto
}

Mots-clés: Fédéralisme brésilien; Plan Real; Privatisations; Réélection; Gouvernement Fernando Henrique Cardoso.

Cet article tente d'expliquer les transformations qui ont eu lieu dans les relations fédératives au cours du premier mandat du gouvernement Fernando Henrique Cardoso. Selon la littérature du fédéralisme, pendant le processus de redémocratisation, les gouverneurs des États sont devenus des acteurs importants, en acquérant de larges pouvoirs de veto contre les actions de l'Éxécutif fédéral, particulièrement contre celles destinées au contrôle de la crise économique. Néanmoins, le gouvernement FHC a été capable de stabiliser l'économie et de recentraliser une partie des rapports fédératifs. Comment cela a été possible ? Ce travail se fonde sur l'hypothèse selon laquelle les difficultés nées du Plan Real, les règles des dettes des États et la réélection aux postes de l'exécutif ont changé les préférences des élites politiques des États, rendant la privatisation des institutions financières des États attractive à leurs gouverneurs, ce qui, à la fin, a permis au gouvernement fédéral de recentraliser une partie des rapports fédératifs brésiliens. 